\title{
Crime in Trinidad and Tobago: the effect of alcohol use and unemployment
}

\author{
Hari D. Maharajh ${ }^{1}$ and Akleema $A l i^{2}$
}

Suggested citation Maharajh HD, Ali A. Crime in Trinidad and Tobago: the effect of alcohol use and unemployment. Rev Panam Salud Publica. 2004;15(6):417-23

ABSTRACT Objective. The purpose of this study was to determine whether unemployment and alcohol consumption were associated with different types of crime in Trinidad and Tobago.

Methods. This study made use of secondary data from the Central Statistical Office of Trinidad and Tobago for the period 1990-1997. Pearson product moment correlations and stepwise multiple regression analysis were used to identify significant predictors of crime.

Results. Unemployment accounted for $69.2 \%$ of the variance for serious crimes. Beer available for home consumption explained $64 \%$ of the variance for minor offenses, and both unemployment and beer available for home consumption accounted for $92.2 \%$ of the variance for minor crimes.

Conclusions. This study provides information that is potentially useful for developing public policies for unemployment and for the sale of beer for home consumption, both of which are associated with crime in Trinidad and Tobago. Reductions in beer available for home consumption - a major public health concern-would significantly reduce the occurrence of minor offenses in this country. Further research is needed on the relationship between unemployment and crime.

Key words Alcohol, crime, public health, Trinidad and Tobago, unemployment.

Criminal activity is a major social problem that governments face. Recently, there has been increased interest in identifying specific predictors of crime that can be used in formulating public policy. Many research designs have been used to examine crime and its predictors. For example, most re-

\footnotetext{
Department of Psychiatry, Faculty of Medical Sciences, The University of the West Indies, Mount Hope, Trinidad, West Indies. Send correspondence to: Hari D. Maharajh, Department of Psychiatry, Faculty of Medical Sciences, The University of the West Indies, Mount Hope, Trinidad, West Indies; telephone: (1 868) 665 3119; e-mail: drharim@ carib-link.net

2 Department of Behavioural Sciences, The University of the West Indies, St. Augustine, Trinidad, West Indies.
}

search that identifies alcohol use as a predictor of crime have been based on two approaches: individual-level analysis and analysis of aggregate-level data. In individual-level studies, the occurrence of crimes is related to individual intoxication, whereas aggregate-level studies demonstrate that an increase in one predictor (e.g., drinking) is followed by an increased rate of violence within that population (1). Aggregatelevel data have been shown useful for cross-cultural comparisons.

The possible existence of a relationship between unemployment and crime (U-C) has been examined extensively in econometric analyses, based on both time series and cross-sectional analysis (2-5). In a review of the empirical evidence, Chiricos (6) argued that the direction of the U-C relationship depends on factors such as type of crime, how employment is measured, and the time period studied.

Major predictors of crime identified to date are alcohol consumption $(1,7)$, unemployment $(8,9)$, spatial dynamics of neighborhood structure (10), handgun sales (11), and the economy (12). Despite attempts to identify predictors of crime, there is general agreement that crimes differ from country to country and that different types of crime have different causes (13). 
FIGURE 1. Crime rates in Trinidad and Tobago for the period 1990-1997

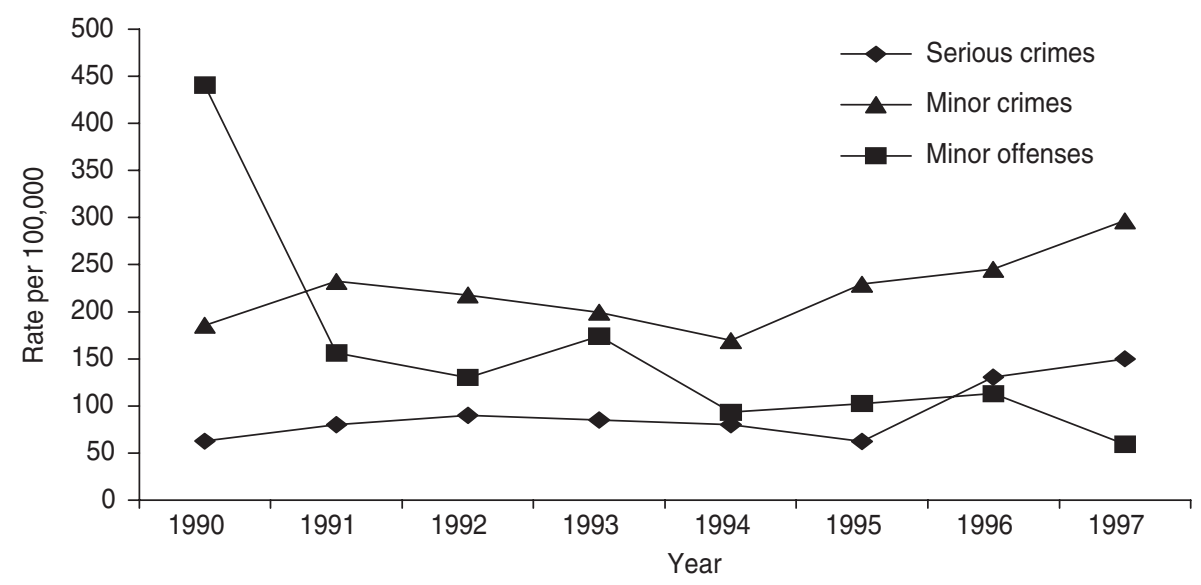

Within the Caribbean setting, previous studies have examined the region as a whole and have focused on suicide and homicide (14), and also on unemployment and crime (8). However, no studies have yet examined aggregate-level data for Trinidad and Tobago. Such studies are needed to identify specific predictors of crime, so that the results can be directed towards the formulation of public health policies with respect to crime within Trinidad and Tobago.

General trends in crime rates have been identified for the period from 1990 to 1997 (Figure 1). Minor offenses (misdemeanors) have decreased sharply from 440.5 per 100000 inhabitants in 1990 to 59.3 per 100000 inhabitants in 1997, with the sharpest decrease occurring between 1990 and 1991. The trend lines for serious crimes and minor crimes showed similar and almost parallel trends. Rates began to decrease from 1991 to 1994 for minor crimes (from 232.5 to 169.5), and from 1992 to 1995 for serious crimes (from 80.1 to 62.4). However, the rates began to increase steadily thereafter, and by 1997 had reached 296.5 for minor crimes and 150 for serious crimes. Of all three types of crime, minor crimes were the most prevalent, with the highest rates throughout the period from 1991 to 1997. The purpose of this study was to investigate the association between these trends for different types of crime in Trinidad and Tobago and two major predictors: alcohol use and unemployment.

\section{MATERIALS AND METHODS}

\section{Description of Trinidad and Tobago}

Trinidad and Tobago is the most southerly of all Caribbean islands and has a population of approximately 1.3 million, with $40.3 \%$ of the population being of East Indian descent, 39.6\% of African descent, $18.4 \%$ of mixed descent and $1.7 \%$ belonging to other ethnic groups. Trinidad has five major towns: Port-of-Spain, San Fernando, Arima, Chaguanas and Pt. Fortin, while Tobago has one major town, its capital Scarborough (15). The per-capita gross domestic product (GDP) is US\$ 8948 (16), with the energy sector (oil, asphalt, mining, and refining) being the major contributor to the GDP (15).

The court system in Trinidad is inherited from the English legal system. Magistrates' Courts are lower criminal courts responsible for preliminary proceedings for offenses. These courts are also involved in civil cases, indictable offenses and summary offenses. The High Court is a court of unlimited jurisdiction in both civil and criminal matters; members of the judiciary sit in the High Court and justice may be imparted through a jury system.

\section{Design}

This study used secondary data from the Central Statistical Office (CSO). The CSO is the sole institution in Trinidad and Tobago responsible for the collection and dissemination of data related to social and economic activities in this country. Data are available for the period from 1990 to 1997. At the time of this study no data were available for the period after 1997.

The following statistics were gathered for the period 1990-1997 to examine the relationship between alcohol use, unemployment, and crime: serious crime, minor crime, minor offenses, liters of alcohol available for home consumption (beer, rum, and stout), and unemployment rates. Serious crimes included all crimes carrying a penalty of imprisonment for five years or longer, and for which prosecution had been instituted in the High Court. Minor crimes included all crimes carrying a penalty of imprisonment for less than five years, and for which prosecutions had been instituted in the High Court. Minor offenses included all offenses for which prosecution had been summarily instituted in the Magistrates' Court. Detailed descriptions of these categories of crime are given in Table 1, which lists the concepts and definitions of crime used by the CSO (17).

Liters of alcohol available for home consumption was used as a surrogate measure for alcohol consumption, as figures for actual alcohol consumption are not tabulated by the CSO. The CSO calculates alcohol available for home consumption based on total production of alcoholic beverages plus imports minus exports. Because the figures for availability of alcohol for home consumption for each year represent new inventory, it follows that production for a given year reflects the population's demand for each product. Therefore, if consumption of a given beverage increases over time, it is likely that production of the item will increase, thus making it more available to consumers in this supplyand-demand system (18). 
TABLE 1. Concepts and definitions of crime, according to the Central Statistical Office report Social Indicators 1985-1992

\section{Serious crimes}

All crimes carrying a penalty of five or more years' imprisonment for which proceedings have been instituted in the High Court. Six classes of serious crime are defined:

Class I. Serious crimes against persons. They include murder, conspiracy to commit murder, manslaughter, infanticide, attempted murder, suicide and attempted suicide, written threat to commit murder, felonious wounding, acts causing or tending to cause danger to life, rape and unlawful carnal knowledge, abduction, defilement and procurement of women; child-stealing; burglary, abortion and concealment of birth, and unnatural offenses.

Class II. Serious crimes against property with violence. They include blackmail and extortion, breaking and burglary, robbery, possession of housebreaking implements by night.

Class III. Serious crimes against property (valued at US\$2 000.00 or more) without violence. They include embezzlement and larceny ${ }^{a}$ by a servant, falsification of account, false pretense, fraud and fraudulent conversion, post office felonies, and larceny in dwelling houses.

Class IV. Serious crimes against property resulting from injury with malicious intent. ${ }^{b}$ They include arson, other malicious damage valued at more than US\$ 1000.00 (excluding private disputes) and cattle maiming.

Class V. Serious crimes defined as forgery and crimes against currency. This class includes forgery (other than currency notes), coinage offenses, and forgery of currency notes.

Class VI. Serious crimes against the state. They include treason, sedition, perjury, riot, criminal libel, [im]personation, ${ }^{\mathrm{c}}$ corruption, fire and other inchoate offenses such as incitement and conspiracy.

\section{Minor crimes}

These are all crimes carrying a penalty of less than five years' imprisonment for which proceedings have been instituted in the Magistrates' Court or the High Court. These crimes are defined as commission or attempted commission of the following:

Indecent assault, assault with intent to commit a felony on officers of the peace (including police), possession of housebreaking implements by day, embezzlement (under US $\$ 2000.00$ ), fraudulent conversion (under $\$ 2000.00$ ), false pretense (under $\$ 2000.00$ ), larceny (under $\$ 2000.00$ ), praedial larceny (under $\$ 2000.00$ ), unlawful possession of property belonging to another (theft), violation of post office ordinance, operation of a brothel, being in enclosed and other premises for an unlawful purpose, assault occasioning actual bodily harm, causing bodily harm, causing bodily harm by reckless driving, escaping lawful custody, and violations of Firearm Act 44/1970.

\section{Minor offenses}

These are offenses for which prosecutions has been summarily instituted in the Magistrates' Court. They involve the following:

Loitering, assault and battery; assault upon a police officer in the execution of his duty, willful obstruction of a police officer in the execution of his duty, offenses against the Persons Act OAPA $1861 \mathrm{~s} 47$; cruelty to animals; breach of the peace, unlawful bearing of a dangerous weapon, malicious damage (under US\$1000.00) except in private disputes, gambling, violation of laws or ordinances regarding liquor licenses and clubs; wild animals and birds; cinemas, theaters and dance halls; agricultural fires; sale of produce; the Children Ordinance; food \& drugs; public mischief; narcotics offenses; violation of the Dangerous Animals Act of 2000 obligating owners to possess a license and insurance to keep a ferocious dog; violation of laws regarding shop opening hours; violation of laws regarding weights and measures; violation of price-of-goods regulations, violation of rationing regulations, and offenses under ordinance such as robbery, blackmail, burglary and deception.

\footnotetext{
a Larceny: For the purposes of this report, this comprises larceny and larceny of postal packages. Note, however, that larceny is considered to exist only when goods worth US\$2 000.00 or more are involved.

${ }^{b}$ This is based on English Law governing criminal liability and is in keeping with the Criminal Damage Act of 1971 which replaced the Malicious Damage Act of 1861. s1(2) of the 1971 act created the aggravated offense of damaging or destroying property with either intention to endanger life or recklessness as to whether life is endangered.

c The original document contains what appears to be a typographical error; we assume "impersonation" is intended here.
}

\section{Analysis}

The Statistical Package for the Social Sciences (SPSS, version 11) was used to conduct all statistical analyses. Differences were considered significant at $P<0.05$. For the analyses, rates for each type of crime (Figure 1) were calculated per 100000 inhabitants by dividing the total number of each type of crime by the total population for that year. Alcohol available for home consumption was calculated as liters of each beverage released for consumption and placed on store shelves per 100000 inhabitants, and the unemployment rate was calculated as a percentage of the available workforce not gainfully employed.

Pearson product-moment correlations were used to examine the overall direction and strength of the relationships between the variables. This was followed by multiple stepwise regression, performed with type of crime (serious crime, minor crime, and minor offenses) as the dependent variable, and with unemployment, liters of beer placed on store shelves, liters of rum placed on store shelves and liters of stout placed on store shelves as the predictor variables. Figures for the predictor variables were lagged one year with respect to the figures for crime rates to account for variations in the latter. These statistical procedures have been used in similar types of research $(11,19)$.

\section{RESULTS}

Between 1990 and 1993, the mean unemployment rate was $19.48 \%$. This rate decreased steadily from 1993 to 1997. For the whole eight-year period, unemployment decreased by $29.0 \%$, from $20 \%$ in 1990 to $14.2 \%$ in 1997 (Figure 2). The trend lines for alcohol consumption (Figure 3) showed that total liters of alcohol available for home consumption were highly dependent on beer availability $(r=0.960, P<0.001)$. Stout was the second most popular alcoholic beverage, with rum available for home consumption ranking third. For rum and stout, availability for 
FIGURE 2. Unemployment trend line in Trinidad and Tobago for the period 1990-1997

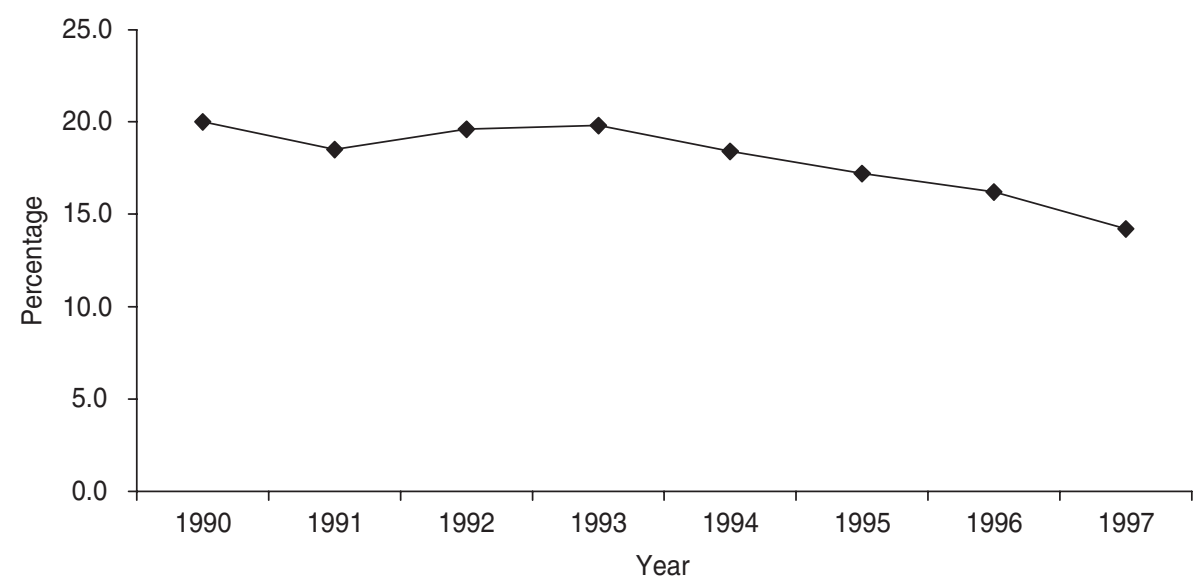

FIGURE 3. Liters of different types of alcoholic beverages consumed in Trinidad and Tobago for the period 1990-1997

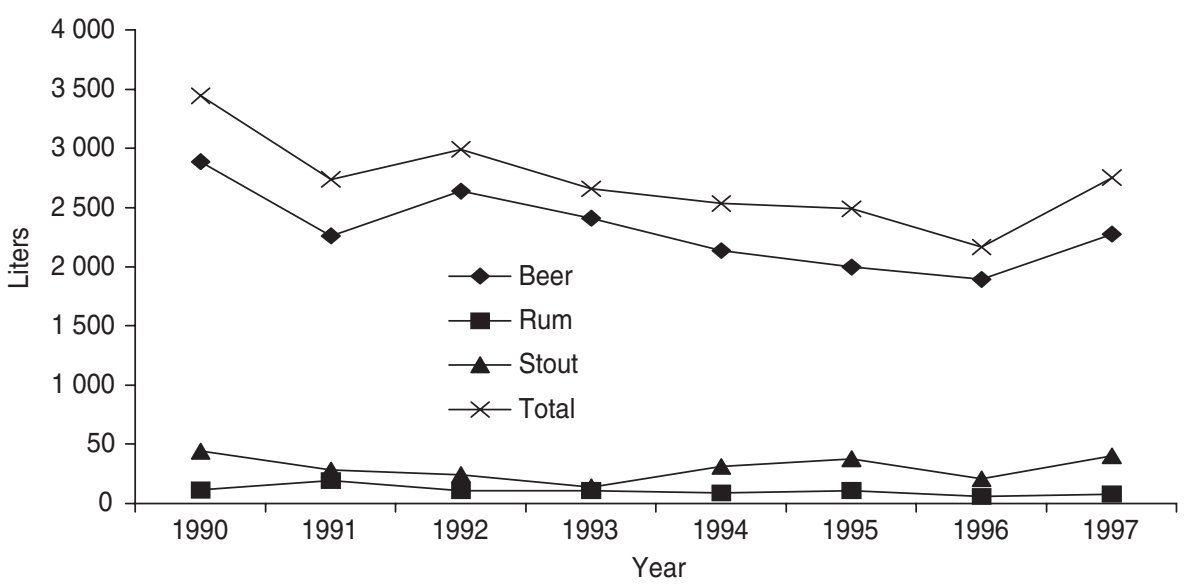

home consumption per 100000 inhabitants was less than 500 liters throughout the period from 1990 to 1997.

The correlation coefficients revealed that unemployment was significantly and inversely correlated with serious crimes $(r=0.832, P<0.05)$ and minor crimes $(r=0.833, P<0.05)$. Minor offenses were directly correlated with unemployment $(r=0.693, P<0.05)$ and beer availability $(r=0.800, P<0.05)$. The correlations are summarized in Table 2.

Stepwise regression analysis revealed three models that accounted for substantial proportions of crime. Table 3 summarizes the results for all regres- for $92.2 \%\left(R=0.960, R^{2}=0.922\right)$ of the variance. In this model unemployment alone accounted for $69.4 \%$ of the variance, while beer availability contributed an additional $22.8 \%$ of the variance. Other predictors were excluded from the model.

\section{DISCUSSION}

This study attempted to identify predictors of various types of crime in Trinidad and Tobago. Overall, it was found that both unemployment and beer available for home consumption were associated with criminal activities in this country. Unemployment accounted for $69.2 \%$ of the variance in serious crime rates and $69.4 \%$ of the variance in minor crime rates. The present analysis identified beer available for home consumption as the sole predictor of minor offenses, accounting for $64 \%$ of the variance. Beer consumption also contributed to minor crimes, accounting for $22.8 \%$ of the variance in the rates of this type of crime.

The beta values in the stepwise multiple regression models (Table 3) confirmed that unemployment was a potentially useful predictor of both serious and minor crimes, but that the direction of the effect was negative, i.e., falling unemployment rates result in higher crime rates. Previous research (2) and economic theory (20) have supported an inverse $\mathrm{U}-\mathrm{C}$ relationship by suggesting that as unemployment decreases, more economic goods and potential crime targets become available. Thus, as unemployment falls, opportunities increase for attempted and successful criminal activities.

Of the three alcoholic beverages compared here, beer was the only one that contributed significantly to crime. This association can be attributed to two factors: the beverage-specific effects of alcohol and the drinking culture or pattern in Trinidad and Tobago. Earlier research has noted the possible differential beverage-specific effects of alcohol on various behavioral outcomes (21). Studies of trends identified in Europe have focused on the "Mellanby effect," which occurs when 
TABLE 2. Correlations between types of crime, unemployment and alcohol availability, by type of beverage, in Trinidad and Tobago, 1990-1997

\begin{tabular}{lcccc}
\hline & \multicolumn{5}{c}{ Type of beverage } \\
\cline { 2 - 5 } Type of crime & Unemployment & Beer & Rum & Stout \\
\hline Serious crimes & $-0.832^{\mathrm{a}}$ & -0.622 & -0.308 & -0.82 \\
Minor crimes & $-0.833^{\mathrm{b}}$ & -0.548 & -0.431 & 0.284 \\
Minor offenses & 0.693 & $0.800^{\mathrm{a}}$ & 0.439 & 0.448 \\
\hline $\mathrm{a} P<0.05$. & & & \\
$\mathrm{b} P<0.01$. & & & &
\end{tabular}

the blood alcohol concentration rises more rapidly and to higher levels when spirits are consumed compared to when beer is consumed. In addition, the differential effects of alcoholic beverages are likely to be directly linked to the drinking culture of the country. Stronger associations have been established between violent behavior and the "explosive" drinking patterns seen in Finland, Sweden and Norway when compared to the "moderate" drinking patterns of France (7). In Sweden, spirit consumption was strongly associated with crime but no association was found for beer or wine consumption. Parker and Cartmill (22), in an analysis of U.S. data, found that the consumption of spirits was directly related to the commission of homicidal acts by white persons, whereas beer consump- tion was linked to the commission of homicidal acts by nonwhite persons.

The drinking culture of Trinidad and Tobago includes the consumption of beer, stout, and rum. However, beer was the most popular of all three beverages from 1990 to 1997, and the amount of this beverage available for consumption in 1997 was 28.32 times as great as the amount of rum and 5.68 times as great as that of stout (Figure $3)$. Because beer is dominant in the drinking context of Trinidad and Tobago, it is more likely than other alcoholic beverages to be a predictor of crime, more specifically minor crimes and minor offenses. In clinical observations we have noted an increase in the numbers of adolescents and young adults seeking treatment for alcoholrelated problems.
Our findings are consistent with those of the Forst and Bennett Caribbean study (8), which found no evidence to support the hypothesis that increases in unemployment are related to increases in crimes. The multiple stepwise regression analyses in Table 3 indicate that although unemployment plays a role in the occurrence of serious and minor crimes (accounting for $69.2 \%$ and $69.4 \%$ of the variance respectively), its predictive effect is negative, as shown by the beta values ( $\beta=$ -0.832 and $\beta=-0.833$ ). However, our study is limited by the fact that the measure of unemployment we used represents global rates at the national level, and thus does not take into account the influence of age or gender. Unemployment rates should differentiate between young men and older men, and between male and female unemployment. Research has shown that the direction of the U-C relationship varies when these differences are taken into account $(5,6)$. The present study is also limited by the fact that alcohol consumption was not measured directly; instead we used availability of alcohol for home consumption as a surrogate measure of consumption. However, we feel the indirect nature of this variable does not undermine the significance of the relationships found in our multiple regression analysis.

TABLE 3. Variables identified by stepwise regression analysis as predicting different types of crime in Trinidad and Tobago, 1990-1997

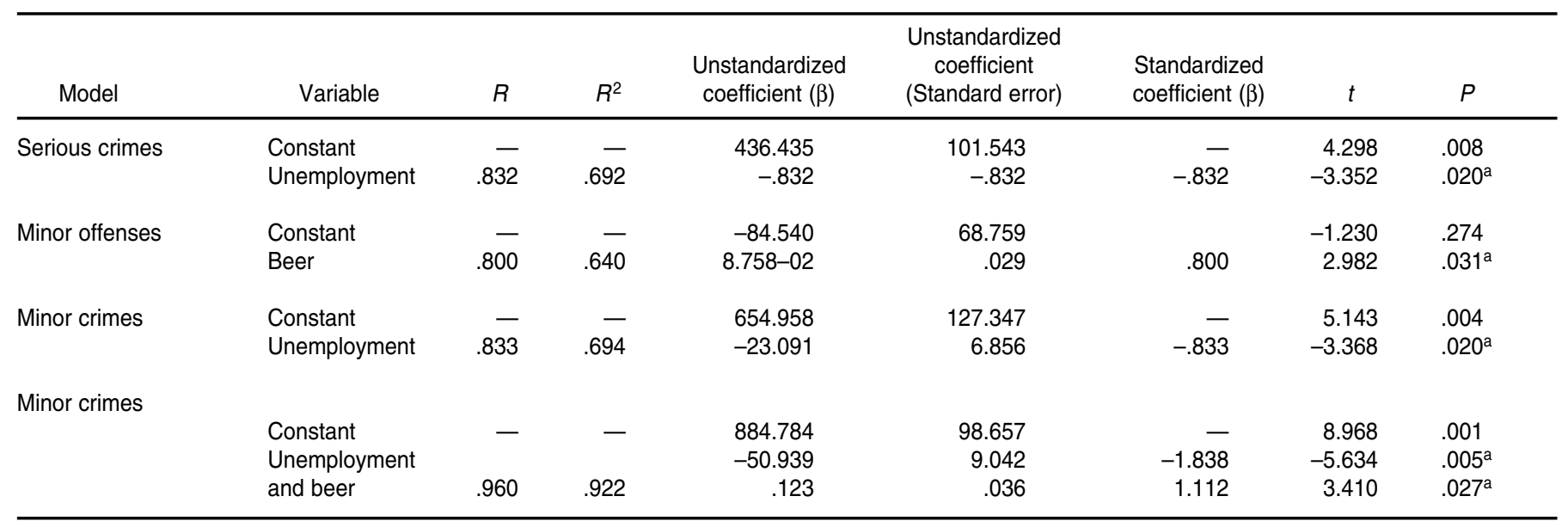

a Significant at $P<0.05$. 
For many decades researchers from different disciplines (e.g., sociology, psychology, and economics) have tried to identify the combination of factors that might account for criminal activities in different countries. Although the $92.2 \%$ variance in minor crimes attributed to unemployment $(69.4 \%)$ and beer available for home consumption $(22.8 \%)$ may seem a high figure, the implications of this association merit further consideration as the results of future research in Trinidad and Tobago and other countries come to light. The role of other factors should be investigated with the same methods to see whether similar correlations and variances are found between these variables in other countries.

Despite the finding that both unemployment and beer available for home consumption are associated with criminal activities in Trinidad and Tobago, crime may also be the result of other phenomena. Other factors that merit study and that may contribute to the variance in rates of serious crime are poverty (e.g., malnutrition, unsanitary dwellings, crowded living conditions) and inequality (uneven distribution of wealth), low educational level, poor moral development, low wages, and mental illnesses. Previous researchers have noted that poverty and inequality should not be neglected in attempting to explain crime $(23,24)$.

This study, an initial attempt to identify predictors of crime, has demonstrated that beer available for home consumption and unemployment are significantly associated with crime in Trinidad and Tobago. Further examination of the U-C relationship is advisable in which the measure of unemployment used takes differences in age, gender, and county into account. The U-C relationship should also be examined across counties and administrative areas in Trinidad and Tobago to establish whether the direction of this relationship remains the same, so that policies implemented to deal with various types of crime can be addressed specifically to the needs of each county or area. We also recommend that future studies use an econ- ometric method so that changes over time can be followed. In addition, measures should be taken to reduce the amount of beer made available for home consumption, as this was the only significant predictor of minor offenses $(64 \%)$ and one of the two predictors of minor crimes $(22.8 \%)$. Reductions in beer available for home consumption may significantly reduce the occurrence of minor offenses in Trinidad and Tobago. This hypothesis, however, has not yet been tested.

The findings of this study have potentially important public health implications for all Caribbean countries now faced with escalating crime, increasing rates of substance abuse, and rising rates of unemployment. Trinidad and Tobago is one of the more developed Caribbean countries, and as other Caribbean islands become more industrialized, it is likely that social and behavioral changes seen in Trinidad and Tobago may be mirrored elsewhere. This study provides an important baseline for further research in the region.

\section{REFERENCES}

1. Rossow I. Alcohol and homicide: a crosscultural comparison of the relationship in 14 European countries. Addiction. 2001;96: S77-92.

2. Elliott C, Ellingworth D. Exploring the relationship between unemployment and property crime. App Econ Lett. 1998;5:527-30.

3. Gould ED, Weinburg BA, David B. Crime rates and local labour market opportunities in the United States: 1970-1997. Rev Econ Stat. 2002;84:45.

4. Kleck G, Chiricos T. Unemployment and property crime: a target-specific assessment of opportunity and motivation as mediating factors. Criminology. 2002;40:649-79.

5. Carmichael F, Ward R. Youth unemployment and crime in the English regions and Wales. Appl Econ. 2000;32:559-71.

6. Chiricos TG. Rates of crime and unemployment: an analysis of aggregate research evidence. Soc Probl. 1987;32:189-212.

7. Lenke L. Alcohol and criminal violence: time series analyses in a comparative perspective. Stockholm: Almquist \& Wiksell; 1990.

8. Forst B, Bennett RR. Unemployment and crime: implications for the Caribbean. Caribbean J Criminol Soc Psychol. 1999;3:1-29.
9. Britt CL. Reconsidering the unemployment and crime relationship: variation by age group and historical period. J Quant Criminol. 1997; 13:405-28.

10. Gorman DM, Speer PW, Gruenewald PJ, Labouvie EW. Spatial dynamics of alcohol availability, neighbourhood structure and violent crime. J Stud Alcohol. 2001;62:628-36.

11. Sorenson SB, Berk RA. Handgun sales, beer sales and youth homicide, California, 19721993. J Public Health Policy. 2001;22:182-97.

12. Lester D, Motohashi Y, Yang B. The impact of the economy on suicide and homicide rates in Japan and the United States. Int J Soc Psychiatry. 1992;38:314-7.

13. Marselli R, Vannini M. Estimating a crime equation in the presence of organised crime: evidence from Italy. Int Rev Law Econ. 1997; 17:89-113.

14. Lester D. Suicide and homicide in Caribbean nations. Percept Mot Skills. 1999;88(3 Pt. 2): 1350.

15. Trinidad and Tobago, Central Statistical Office. Statistics at a glance, 2001. Port-of-Spain (Trinidad and Tobago): Ministry of Planning and Development, Central Statistical Office; 2001.
16. World Health Organization. CountriesTrinidad and Tobago [Internet Site]. Available from: http:/ / www.who.int/country/tto/en/. Accessed 1 February 2004.

17. Trinidad and Tobago, Central Statistical Office. Social Indicators 1985-1992. Port-ofSpain (Republic of Trinidad and Tobago); 1996. p. $182-4$.

18. Dass J. Measurement of alcohol consumption in Trinidad and Tobago. Port-of-Spain (Trinidad and Tobago): Ministry of Finance, Custom and Excise Division; Government of Trinidad and Tobago; 2004.

19. Preti A, Miotto P. Some social correlates of homicide rates in Italy. Psychol Rep. 1999;85 (3 Pt 1):770.

20. Cantor D, Land KC. Unemployment and crime rates in post-world War II United States; a theoretical and empirical analysis. Am Soc Rev. 1985;50:317-32.

21. Smart RG. Behavioural and social consequences related to the consumption of different beverage types. J Stud Alcohol. 1996;57: 77-84.

22. Parker RN, Cartmill RS. Alcohol and homicide in the United States 1934-1995-or one reason why U.S. rates of violence may be 
going down. J Crim Law Criminol. 1998;88: 1369-98.

23. Tsushima M. Economic structure and crime: the case of Japan. J Socio-Economics. 1996;25: $497-515$.
24. Hojman DE. Explaining crime in Buenos Aires: the roles of inequality, unemployment and structural change. Bull Latin Am Res. $2002 ; 21: 121-8$.
Manuscript received on 7 April 2003. Revised version accepted for publication on 12 March 2004.

RESUMEN Objetivo. Determinar si el desempleo y el consumo de alcohol se asociaban con distintos tipos de delincuencia en Trinidad y Tabago.

Métodos. El estudio se realizó con datos secundarios obtenidos de la Oficina Central de Estadísticas de Trinidad y Tabago para el período de 1990-1997. Se aplicaron correlaciones de Pearson del tipo producto-momento y análisis de regresión múltiple por eliminación progresiva (stepwise regression) para identificar los principales factores pronósticos relacionados con la delincuencia.

Resultados. El desempleo explicó $69,2 \%$ de la varianza en la frecuencia de delitos graves. La disponibilidad de cerveza para consumo en el hogar explicó 64\% de la varianza en la frecuencia de infracciones menores, y el desempleo junto con la disponibilidad de cerveza para consumo en el hogar explicaron $92,2 \%$ de la varianza en la frecuencia de delitos menores.

Conclusiones. Este estudio proporciona información que puede ser útil para idear políticas contra el desempleo y la venta de cerveza destinada al consumo doméstico, factores que se asocian con la delincuencia en Trinidad y Tabago. Si se redujera la disponibilidad de cerveza para consumo en el hogar — problema de salud pública importante-, la frecuencia de infracciones menores se reduciría notablemente en este país. Hacen falta más investigaciones que exploren la relación entre el desempleo y la delincuencia.

\title{
Conference on Overcoming Health Disparities
}

\author{
Dates: $\quad 6-10$ October 2004 \\ Location: Sheraton Hotel Atlanta \\ Atlanta, Georgia, United States of America
}

Two organizations, the Community-Campus Partnerships for Health (CCPH) and The Network: Towards Unity for Health (The Network: TUFH), are cosponsoring an international conference entitled "Overcoming Health Disparities: Global Experiences from Partnerships Between Communities, Health Services, and Health Professional Schools." The conference will focus on the persistent problem of health disparities within nations and between nations around the world, highlight promising strategies for overcoming the disparities, and stimulate constructive actions that can be taken at multiple levels, including cross-sector cooperation and coordination that bring communities, health services, and health professional schools together as partners for change.

The conference will include keynote addresses, mini-workshops, poster presentations, community site visits, and other activities. The conference's thematic tracks will focus on promising practices in such areas as advocacy and policy change, health promotion and disease prevention, creating healthy settings, translating research into practice, building regional and international networks for change, addressing the social determinants of health, and innovation in health professions education. The event is intended for participants from around the world, including representatives of community agencies, government organizations, foundations, health care delivery organizations, health care providers, and faculty, administrators, and students of educational institutions for health and social care professions.

The registration fee for the conference for members of the cosponsoring groups is US\$ 550 , and the fee for nonmembers is US\$ 600. The charge for students is US\$ 200.

\author{
Information: \\ Overcoming Health Disparities Secretariat \\ P.0. Box 616, \\ 6200 MD Maastricht, the Netherlands \\ Telephone: 31-43-3881524/1522 • Fax: 31-43-3884142 \\ E-mail: secretariat@network.unimaas.nl \\ Web site: http://www.the-networktufh.org/conference
}

